\title{
A Plebe do Açúcar: A População Livre na Retomada da Jurisdição Portuguesa na Capitania de Pernambuco (Séc. XVII-XVIII)
}

Kalina Vanderlei SILVA ${ }^{\bullet}$

\begin{abstract}
Resumo: Este artigo pretende apresentar um panorama da estrutura social açucareira a partir da retomada da jurisdição portuguesa sobre a capitania de Pernambuco em 1654, observando especificamente os grupos sociais livres urbanos que vivenciaram um crescimento significativo durante o governo holandês e a partir dele. Considerando o discurso dos cronistas, dados inquisitoriais e correspondência administrativa, buscamos analisar as modificações sociais ocorridas então.
\end{abstract}

Palavras-Chave: Pernambuco; Sociedade açucareira; Governo português.

\section{Introdução}

Em 1654, as tropas luso-brasileiras puseram fim ao domínio da companhia holandesa WIC sobre a Capitania de Pernambuco e suas vizinhas, abrindo caminho para a reinserção dessa região no Império Português. O período que se estendeu entre essa data e a primeira década do século XVIII, quando a povoação do Recife foi transformada em vila, foi marcado por mudanças políticas e sociais geradas pela guerra, mas também pelo crescimento populacional nos núcleos urbanos. E se, por um lado, as inquietações políticas desse período, entre governo de Pernambuco, Câmaras de Olinda e Recife e Governo Geral, foram estudadas por uma historiografia que se debruçou sobre a

\footnotetext{
- Pesquisa desenvolvida com o apoio da FACEPE - Departamento de História - Faculdade de Formação de Professores de Nazaré da Mata, Universidade de Pernambuco - UPE - 55800-000 - Pernambuco - PE Brasil. E-mail: gehscal@uol.com.br
} 
passagem do XVII para o XVIII, por outro lado, a situação social desse momento foi pouco analisada ${ }^{1}$. Assim, procuramos aqui traçar um panorama das modificações sociais, do crescimento populacional e da diversificação dos grupos livres que se entrelaçaram com o surgimento de uma elite mercantil em Recife e com as mudanças no cenário político da região².

\section{O Cenário Urbano: Recife e Olinda em fins do Século XVII}

Em fins do século XVII, Olinda e Recife eram, política e economicamente, os dois núcleos urbanos mais importantes da Capitania de Pernambuco. O Recife, particularmente, estava em vias de se transformar na cidade mais populosa da região. Em uma e outra pululavam pobres livres, escravos urbanos, pretos e pardos forros, senhores de engenho e grandes comerciantes.

Desde 1654, a capitania vinha sofrendo grandes alterações políticas e sociais com a retomada do território pela Coroa portuguesa. Até então controlada por uma companhia de comércio holandesa, a partir de sua reinserção no império português, Pernambuco passara a vivenciar uma nova fase: de capitania particular e donatarial tornara-se capitania régia, gerida por um funcionário, um governador. E essa fase foi marcada por uma série de eventos e situações turbulentas que o novo governo precisou enfrentar, algumas geradas por sua própria instalação ${ }^{3}$.

Economicamente, foi um momento de reconstrução da indústria açucareira e de crise do açúcar, visível nas décadas de 1680 e 1690 quando o preço do açúcar correspondia a apenas 1/3 daquele da década de 1650. Por outro lado, os comerciantes se desenvolviam a olhos vistos, tanto em Pernambuco quanto na Bahia. E, a partir das primeiras décadas do XVIII, também outros setores, como a pecuária sertaneja e os atanados, sem esquecer a significativa agricultura de subsistência que secundava a produção de cana: pequenos lotes familiares de mandioca e milho em torno de núcleos urbanos como a Paraíba, Goiana, São Miguel de Ipojuca, abasteciam o mercado das vilas açucareiras. 
Essa agricultura envolvia diretamente a população livre pobre, assim como a pesca, tão importante no abastecimento das povoações populosas da zona açucareira que levara o governo holandês a criar um mercado especializado em pescado para abastecer o Recife e a Cidade Maurícia ${ }^{4}$.

Além do peixe, também a coleta de caranguejos e mariscos tinha um papel vital no abastecimento cotidiano da população da zona canavieira, principalmente para as camadas mais pobres dos núcleos urbanos, inclusive movimentando uma importante parcela do comércio ambulante. A coleta, assim como a pesca e a agricultura de subsistência, gravitava em torno dos engenhos e dos núcleos urbanos da região ${ }^{5}$.

Esse foi 0 cenário encontrado pelos primeiros governadores de Pernambuco: núcleos urbanos em crescimento, cercados por pequena produção de subsistência e extensos canaviais, muitos dos quais devastados pela guerra. Enquanto nas ruas das cidades grassavam epidemias - em 1685, a febre amarela assolou o Recife -, cresciam também áreas de conflito nas margens da capitania, como o quilombo de Palmares e as áreas indígenas tapuias rebeladas.

Além disso, os exércitos inchados, o despovoamento do mundo rural, a migração da população livre para o sul e o banditismo generalizado tinham-se transformado em graves preocupações administrativas, além de sociais, desde o primeiro governador, Francisco Barreto de Menezes ${ }^{6}$.

A situação política entre Olinda e Recife também se alterava. A povoação do Recife crescera consideravelmente no período holandês e com ela sua população urbana e seu grupo de comerciantes. Ao assumir a capitania, o governador Barreto de Menezes, um português com interesses comerciais, havia mantido a capital no Recife, apesar dos protestos dos senhores de engenho sediados em Olinda. No entanto, quando André Vidal de Negreiros, senhor de engenho paraibano, substituiu Menezes no governo, Olinda voltou a ser a capital. Mas as querelas políticas entre os senhores de engenho, comerciantes e governadores portugueses apenas começavam, tendo como pano de fundo o crescimento demográfico e comercial do Recife 
em contraste com a estagnação de Olinda. Estagnação, todavia, que não ofuscava a grande influência política que sua Câmara detinha junto ao governo da capitania e às capitanias anexas ${ }^{7}$.

Por sua vez, o Recife continuava a exercer a função de centro defensivo, com a reelaboração da linha física de defesas e a reorganização das tropas régias. Era em suas ruas que estava estacionado o principal quantitativo militar em Pernambuco, e, das fileiras dos seus pobres, é que logo sairia a maior parte dos braços armados litorâneos empurrados para a conquista do sertão ${ }^{8}$.

A Vila de Olinda, tornada cidade em 1676, apesar das dificuldades políticas na disputa pela sede da capitania, mantinha sob sua jurisdição um território extenso. Mas isso não impediu que fosse desertada pela nobreza da terra e se tornasse basicamente espaço de moradias populares: Em 1691, os senhores de engenho que atuavam como oficiais da Câmara chegaram a escrever ao rei solicitando a reconstrução dos edifícios da governança, a sede da Câmara e a cadeia, arruinados desde o período holandês, pois, segundo eles, o abandono desses prédios contribuía para "ficar despovoado o alto da Cidade" que, antes do incêndio da vila, era ocupado preferencialmente pelas elites ${ }^{9}$.

O incêndio de Olinda pela WIC havia se tornado um marco: antes dele, as crônicas ressaltavam os muitos conventos, a riqueza e magnificência dos templos jesuítas, franciscanos, carmelitas e beneditinos, enfatizando também o ativo comércio na parte baixa: Ambrósio Fernandes Brandão, por exemplo, registrou que "dentro da vila de Olinda habitam inumeráveis mercadores com suas lojas abertas, colmadas de mercadorias de muito preço, de toda a sorte em tanta quantidade que semelha uma Lisboa pequena." O holandês Baers, por sua vez, observou que ao sul do bem construído centro havia uma encruzilhada onde os mercadores reunidos 'constituíam bolsa'

Mas a Olinda pós-restauração esteve marcada pelo contraste entre o discurso que ressaltava essa antiga magnificência e a nova decadência, o que pode ser visto, por exemplo, na descrição que o Capitão Varela Berredo Pereira fez dela em 1689: 
[Olinda] foi antigamente muito populosa, rica e autorizada, com grandes e formosas casarias de pedra e cal, todas de dois e de três sobrados, e famílias muito nobres, donde havia grande e considerável negócio e muita abastada de riquezas, (...) ficou arruinada de todo, de que hoje não há mais que umas memórias dos arruinados edifícios que ainda hoje estão mostrando o que foram e hoje haverá nela 500 fogos de gente pobre e casas pequenas, que os ricos todos moram por fora, por suas fazendas. ${ }^{11}$

Apesar desse desprezo que o Capitão, um morador do Recife, demonstrava para com a sede da Capitania, consonante com o despertar das disputas entre as duas cidades, Olinda continuava a ser um centro influente sobre a sociedade açucareira que se estendia do Recôncavo baiano às vizinhanças de Natal, no Rio Grande do Norte. Em sua câmara se abrigavam os senhores de engenho mais influentes, que constituíam a elite dos restauradores e que usavam o Senado para pleitear mercês.

Do outro lado do rio Beberibe, entretanto, o Recife crescia e com ele uma nova elite de mercadores reinóis e uma miríade de grupos sociais livres que permaneceria à margem das querelas políticas da elite açucareira.

\section{A População Livre das Vilas Açucareiras de Pernambuco}

No século XVIII, a América Portuguesa como um todo viveu um considerável crescimento populacional ligado a um surto migratório reinol, ao crescimento interno da população colonial e ao tráfico de escravos ${ }^{12}$. Esse aumento facilitou construções sociais novas em algumas regiões, como a recém colonizada Minas Gerais e o interior paulista, ambos em desenvolvimento a partir da descoberta das minas. As diversas contendas entre reinóis e colonos, que explodiram nesse período, derivavam principalmente do aumento do número de migrantes portugueses. Em Pernambuco, esses conflitos se deram nas primeiras décadas do século, uma vez que a vinda de 
colonos aconteceu bem mais cedo nessa região, ainda no século XVII, a partir de uma leva migratória que foi responsável, juntamente com o aumento do tráfico de escravos, pelo fato de Pernambuco e Bahia representarem, nos Seiscentos, 3/4 da população colonial ${ }^{13}$.

No século XVIII, Lisboa era o maior núcleo urbano do império português, com 180.000 habitantes, seguida por Salvador que, em 1775 , possuía $35.253^{14}$. No fim do século, Salvador já contava com 60.000 habitantes, equiparando-se a Lima, um dos maiores centros urbanos da América hispânica, também com 60.000 habitantes. A única cidade das Américas então maior do que ambas era a Cidade do México, com 100.000 habitantes ${ }^{15}$.

A sociedade açucareira, do Recôncavo baiano aos engenhos do Rio Grande, constituía-se então como um complexo sócio-econômico cujos pólos principais eram a cidade de Salvador, sede do Governo Geral e do comércio do Recôncavo, e a rede Recife/Olinda, que dominava o comércio e exercia influência política sobre as capitanias anexas. O complexo apresentava características estruturais semelhantes, baseadas na escravidão, no latifúndio e no comércio canavieiro, mas também em cidades que funcionavam como centros comerciais, administrativos e culturais para o entorno dos engenhos.

A estrutura social açucareira começara a se definir no século XVI e seus grupos livres foram se tornando mais complexos ao longo do século XVII até que no século XVIII, dividiram-se em três níveis: no topo da pirâmide social, os representantes dos poderes militar, civil e religioso, além dos senhores de engenho; seguidos por uma massa de população livre, composta de funcionários subalternos, soldados burocráticos e pequenos comerciantes, taberneiros, vendeiros, e artesãos; e, embaixo, escravos e vagabundos livres ${ }^{16}$.

A população livre, no século XVI, foi formada com reinóis emigrados voluntários, basicamente artesãos e camponeses, aos quais se somaram os degredados enviados pela Coroa como 'povoadores'. Estes últimos, todavia, não tiveram uma boa acolhida em Pernambuco, então uma capitania particular 
governada pelo donatário Duarte Coelho, para quem os degredados eram uma gente improdutiva, fadada à vadiagem, e que:

nenhum fruto nem bem fazem na terra, mas muito mal e dano e, por sua causa, se fazem cada dia males e temos perdido o crédito que até aqui tínhamos com os indígenas. (...) não são para nenhum trabalho, vem pobres e nus e não podem deixar de usar de suas manhas (...). ${ }^{17}$

Esses homens e mulheres encontraram ali toda sorte de dificuldades, pois eram em sua maioria exilados temporários que não conseguiam se inserir como mão-de-obra em uma sociedade com poucas perspectivas de aproveitá-los produtivamente ${ }^{18}$.

Apesar disso, durante as primeiras décadas do século XVI, os degredados representaram um importante contingente colonizador da zona do açúcar, mas que foi diminuindo significativamente a partir do final do século. E, durante o século XVII, eram principalmente condenados temporários que muitas vezes conseguiam regressar ao Reino, fato que os tornava pouco significativos enquanto elementos colonizadores ${ }^{19}$. Já o imigrante comum do século XVII era oriundo das camadas médias da sociedade portuguesa: artesãos, agricultores, comerciantes ou membros da pequena nobreza, como o próprio Duarte Coelho, que vinham tentar a sorte na zona açucareira. Foi a partir desses personagens que, no final dos Quinhentos, as camadas livres urbanas começaram a se desenvolver em povoações como Olinda, Igarassu, a vila de Conceição e a Cidade da Paraíba, contribuindo para a estruturação do trabalho livre em atividades bastante diversificadas. Tal situação está registrada nos inquéritos do visitador Heitor Mendonça Furtado, realizados nas vilas de Olinda, Igarassú, Itamaracá e Paraíba na década de 1590, e que descrevem a constituição de grupos sociais livres pobres com ofícios diversos, apontando a configuração de um mercado de trabalho livre em Pernambuco já nesse período ${ }^{20}$. 
Entre os tipos sociais que participaram da visitação estavam uns poucos escravos negros, índios, mamelucos e uma maioria de reinóis, em detrimento de mazombos e mestiços. Isso não significa que os reinóis compunham o grupo numericamente majoritário de Pernambuco no século XVI, pois sua predominância nos autos pode apenas insinuar o pequeno interesse de índios, mestiços e escravos negros nas atividades do Santo Ofício e da Igreja Católica, em um período em que a fusão cultural ainda não tornara os valores ibéricos preponderantes.

Quando da investigação feita pelo visitador, as vilas açucareiras já dispunham de um repertório de ofícios mecânicos disponíveis como atividades profissionais para a população livre. Muitos deles ligados aos engenhos, mas outros eminentemente urbanos: mercadores, sapateiros, alfaiates, boticários, pasteleiros, barbeiros, padeiros, vendedores e vendeiras, marinheiros, pintores, mestres-escolas. Profissões que remetem à vida urbana, e a grande maioria das quais, nos autos, ocupadas por reinóis.

A intensa participação dos reinóis na vida urbana de fins do XVI é visível no fato de ocuparem, nesse momento, mesmo os ofícios considerados mais degradantes pelo imaginário ibérico, como criados e pajens. Também a incidência de pescadores reinóis marcou sua presença em uma ocupação que pouco depois seria dominada pelos índios ${ }^{21}$.

Tanto os pescadores quanto os criados e pajens eram trabalhadores mecânicos, atividades desonrosas para o imaginário barroco. Que brancos reinóis assumissem tais 'ocupações degradantes' era um indício da escassez de outros tipos humanos ocupando essas funções, em contraste com um excedente de brancos que, na impossibilidade de assumirem a tão sonhada posição de proprietários de terras, eram obrigados a realizar esses ofícios.

Durante esse período, o cenário do trabalho mecânico colonial ainda era dominado por atividades ligadas principalmente à indústria da cana. A documentação inquisitorial, apesar de centralizada nos espaços urbanos, 
apresenta como atividade profissional mais incidente o ofício de lavrador, tanto de cana quanto de mandioca e mantimentos. A lavra, principalmente de cana, se distanciava do trabalho mecânico, assim como do cenário urbano, apresentando-se como atividade honrosa, ligada à propriedade da terra e ao status de senhor. A lide com a terra era mais honrosa que qualquer trabalho mecânico. Mas os registros inquisitoriais também mencionam uma diversidade de ocupações mecânicas ligadas ao engenho: feitores, carpinteiros, calafates, torneiros, purgadores, ferreiros, mestres de açúcar, serralheiros, carreiros, vinhateiros, vaqueiros, seleiros, oleiros e mestres de fazer engenho.

Por outro lado, a segunda profissão mais incidente foi a de mercador: uma atividade inserida no contexto urbano, mas que pela própria natureza exportadora da agroindústria canavieira, interligava a zona rural e a produção para o mercado externo. Dos quatorze mercadores mencionados nas denunciações e confissões, treze eram reinóis, dentre os quais quatro identificados como cristãos-novos. Os reinóis monopolizaram o comércio de grosso trato açucareiro até o século XVIII, mas, no fim do século XVI exerciam também atividades no pequeno comércio. Eram os tratantes, comerciantes menores, vendedores de balcão, e aqueles que trabalhavam diretamente com a venda. Atividades que, a partir do século XVII, passariam a ser desenvolvidas principalmente por homens de cor.

Houve ainda aqueles que se apresentaram como 'vivendo de sua indústria', outra denominação para o trabalho mecânico, citadino ou rural. $\mathrm{E}$ no caso urbano, essa indústria poderia indicar atividades desenvolvidas no serviço doméstico, venda de comestíveis ou mesmo na mendicância. Das poucas mulheres que declararam ocupação profissional própria nos inquéritos, com exceção das escravas e forras, quatro eram mulheres reinóis, uma delas vendedora, duas que 'viviam de sua indústria' e uma padeira. Esta última, a única pessoa, nos autos, a exercer essa profissão que, juntamente com a de pasteleiro e pintor, oferece pista acerca da diversificação nascente do mercado de 
trabalho livre urbano e de uma incipiente dinâmica urbana, visto serem atividades supérfluas para a produção do açúcar.

Dos ofícios mecânicos, o mais incidente nos autos do Visitador foi o de carpinteiro. Situação pouco surpreendente, considerando sua importância nos engenhos. No entanto, dos treze carpinteiros apontados, três residiam nos núcleos urbanos de Olinda e Itamaracá, quatro se declararam moradores nas vilas de Itamaracá, Igarassu e Cidade da Paraíba, não especificando se no núcleo urbano ou na zona rural, um era baiano estante na vila de Olinda, e apenas cinco eram declaradamente moradores de fazendas e engenhos. Ou seja, mesmo para uma atividade com conotações nitidamente voltadas para a agroindústria exportadora, a área açucareira do Quinhentos já oferecia uma multiplicidade de campos de atuação ${ }^{22}$.

O aumento do tráfico de escravos no século XVII forneceu novos elementos para esse contexto social. O crescimento da população escrava contribuiu para o crescimento da população mestiça e do número de forros. Assim, os oficiais mecânicos já estabelecidos adquiriram escravos que se tornaram, por sua vez, eles próprios oficiais mecânicos. Por outro lado, emergiu dessa camada um grupo de artesãos forros que engrossou as fileiras dos pobres produtivos a ponto de, no século XVIII, já representarem a maior parte dos componentes do que o cronista Vilhena denominou como de 'povo mecânico'23.

A competição que o trabalho escravo oferecia ao trabalho livre era uma característica comum à sociedade açucareira urbana. E no século XVII, com o crescimento da população e do tráfico, essa competição se acirrou, e as camadas livres intermediárias, onde os trabalhadores mecânicos se situavam, começaram a receber cada vez mais mestiços e pretos forros. Unia-os o trabalho mecânico e a ausência de terras. E apesar de muitos conseguirem juntar capital suficiente para abrir oficinas, os ofícios mecânicos eram estigmatizados pelo imaginário colonial. Situação que só aumentou com o acréscimo da escravidão. O chamado 'trabalho mecânico' era considerado mácula grave e tendia a se tornar um obstáculo em uma possível ascensão social ${ }^{24}$. 
Assim, foi durante o Seiscentos que aumentou a participação de pretos e pardos livres no mercado de trabalho urbano, mudando o panorama do trabalho livre nas vilas açucareiras, pois gradativamente foram ocupando, juntamente com os escravos, as atividades que no fim do século XVI eram desenvolvidas por reinóis. No século XVII, homens de cor livres eram encontrados atuando principalmente como estivadores, saveiristas, marinheiros e trabalhadores de obras públicas. Nessa última ocupação, na Salvador seiscentista, a administração colonial inclusive preferia empregá-los no lugar dos escravos. Mas pretos e pardos ocupavam também, em menor escala, profissões liberais do serviço público. Eram, além disso, mestres em artes mecânicas, ourives, escultores, entalhadores, pedreiros, calafates, alfaiates, marceneiros e pintores ${ }^{25}$.

Outro ramo privilegiado para a atividade dos libertos era o pequeno comércio ambulante, onde homens e mulheres atuavam como tendeiros e ganhadeiras. Mas era exatamente nesse ramo que a concorrência com o trabalho cativo se mostrava mais acirrada $^{26}$. Por outro lado, essa convivência de livres e escravos nos mesmos ofícios pode ter criado uma proximidade em suas condições sociais durante os séculos XVII e XVIII ${ }^{27}$. Apesar do imaginário barroco e da hierarquia estamental cuidarem de delimitar as distinções entre eles, fazendo com que por mais similar que fossem as condições de vida de um escravo e de um livre exercendo a mesma profissão, sua condição jurídica seria sempre culturalmente marcante, mantendo o escravo um degrau abaixo do livre pobre.

Essa convivência se dava, muitas vezes, nas corporações de ofícios, bastante atuantes nas vilas açucareiras desde o século XVII, como, por exemplo, a corporação dos pescadores. A atividade pesqueira foi inicialmente desenvolvida por indígenas assimilados pela sociedade colonial, mas a partir do século XVII os pretos forros e os pardos passaram a dominar este mercado, criando aldeias pesqueiras ao longo da costa de Pernambuco. A importância do pescado no abastecimento dos núcleos urbanos da capitania contribuiu, por sua vez, para o desenvolvimento de 
uma gama de especializações na área, com os jangadeiros, os pescadores de alto mar, os camaroeiros e os caranguejeiros, além dos pescadores, tanto escravos como livres pobres ${ }^{28}$.

Nesse sentido, o pequeno comércio ambulante, as artes manuais e a atividade piscatória foram ramos econômicos que forneceram o campo de atuação para aqueles grupos sobre os quais recaíam as mazelas que a sociedade escravista reservava para sua população livre pobre. Carecendo de estabilidade social, e a não ser que possuíssem capital suficiente para montar oficinas, em geral, esses personagens atuavam como ambulantes. Além disso, apesar do recrutamento para a tropa burocrática teoricamente excluir os homens produtivos - o que nem sempre acontecia -, eles deviam, de qualquer forma, inserirse nas tropas auxiliares, que também participavam dos conflitos no interior, acrescentando mais uma dificuldade a seu cotidiano $^{29}$.

E no século XVIII, esses personagens tão diversos, que constituíam as camadas mais baixas e quase sempre indefinidas da sociedade livre no mundo do açúcar, passaram a ser classificados pelo imaginário colonial como membros da plebe, a populaça ou povo miúdo. $O$ conceito de plebe, vigente na sociedade açucareira, descendia diretamente do conceito ibérico de peonage, conceito este difícil de ser aplicado na América portuguesa, pois dizia respeito ao estrato mais baixo da ordem estamental ibérica, que nas vilas açucareiras perdia o sentido junto aos mestiços e pretos livres e forros ${ }^{30}$. No Setecentos, a sociedade de ordens - que as elites açucareiras se esforçaram por fazer valer na América portuguesa - se dividia, teoricamente, em três estados, sendo que o terceiro, o povo, deveria englobar todos aqueles que não pertencessem ao clero ou à nobreza, inclusive os grandes comerciantes e burocratas. Mas, uma vez que o próprio imaginário açucareiro no século XVIII separava não apenas os senhores de terra, mas também os grandes comerciantes enriquecidos, do grosso da população livre, fazia-se necessário uma redivisão do Terceiro Estado, e de dentro do conceito de povo surgiu o de plebe: o mais baixo do povo, os vadios, os criminosos, mas também os libertos e os 
oficiais mecânicos ${ }^{31}$. Uma noção usada por cronistas que no XVIII, imbuídos do imaginário barroco, procuravam ordenar e classificar a sociedade açucareira, como Domingos Loreto Couto, que em meados do século escreveu:

Sendo a Nobreza alma de huma República, o seu corpo se compoem de homens mecanicos, assim chamados das artes mecanicas, ou servis, que exercitão, como carpinteiros, pedreiros, Alfayates etc, e de povo miudo, que he a gente Popular, Plebe, e Povo. (...)

Não he facil determinar nestas Provincias quaes sejão os homens da Plebe; porque todo aquelle que he branco na cor, entende estar fora da esfera vulgar. Na sua opinião, o mesmo he ser alvo, que ser nobre, nem porque exercitem officios mecanicos perdem esta presumpção, (...) O vulgo de cor parda, cõ o immoderado desejo das honras de que o priva não tanto o acidente, como a substancia, mal se acomoda com as diferenças. $O$ da cor preta tanto se vê com a liberdade, cuida que nada mais lhe falta para ser como os brancos. ${ }^{32}$

Uma descrição que apontava a grande diversidade social e étnica das vilas açucareiras, a eterna busca por validação social das camadas livres mais baixas e as tentativas do imaginário açucareiro em ordenar e definir sua sociedade.

Essa plebe de Pernambuco se encontrava tanto nos centros urbanos quanto na zona rural. Nesta, em mocambos isolados ou em pequenos povoados localizados em matas marginais a engenhos. O francês Tollenare, em suas andanças pela área canavieira no começo do século XIX, descreveu os mocambos que encontrou nessas matas e seus habitantes: moradores livres brancos, pretos e pardos, quilombolas e mesmo salteadores; uma parcela da população que ocupava espaços ausentes de controle do Estado ${ }^{33}$.

No meio urbano eram os artesãos e pequenos comerciantes que se destacavam. O comércio, que era considerado 'mácula' pelo imaginário barroco, foi vivenciando, ao longo do século XVII e principalmente durante o XVIII, um abismo entre os pequenos mercadores e os comerciantes de grosso trato. Estes, que 
monopolizavam a corretagem de açúcar e escravos, foram gradativamente ganhando importância no contexto colonial e junto à Coroa, assumindo um status social de elite e se distinguindo dos pobres livres. Enquanto isso, o comércio ambulante prosperava, assim como as vendas de secos e molhados que negociavam principalmente alimentos e bebidas alcoólicas para escravos ${ }^{34}$.

Mas foi o comércio ambulante que teve o mais importante papel no abastecimento da população urbana açucareira e como tal era disputado entre brancos, pretos, pardos forros, mulheres de diferentes castas e escravos, ou seja, pelos membros da plebe açucareira. As mulheres, especificamente as pretas escravas ou forras chamadas de ganhadeiras, vendiam miudezas, pescados, quitutes, legumes e frutas, ocupando o espaço urbano de tal forma que no século XIX chegaram a dominar a comercialização de gêneros alimentícios básicos em Salvador ${ }^{35}$.

Os homens, por sua vez, além de participarem do comércio volante, atuavam como tendeiros: artesãos sem recursos para montar oficinas que exerciam seu ofício em tendas de pano armadas nas praças. Eram, em geral, homens de cor livres e forros, sem acesso à propriedade de escravos e que, como as mulheres de tabuleiro, competiam com os escravos de ganho.

O desenvolvimento desse comércio volante esteve atrelado ao próprio crescimento urbano das vilas do açúcar e à diversificação social promovida pela migração reinol e pelo aumento do número de escravos na região ${ }^{36}$. E se em fins do século XVI era possível encontrar um significativo número de brancos desenvolvendo atividades mecânicas nos núcleos urbanos de Pernambuco, a partir do XVII, esse mercado passou a ser dominado pelo trabalho escravo e pelo aumento da participação de homens de cor livres nas mesmas atividades. Logo, pretos e pardos eram a parcela majoritária dos oficiais mecânicos de Pernambuco.

O mercado de trabalho livre, no entanto, mesmo com a concorrência com os escravos, foi se desenvolvendo de tal forma que favoreceu inclusive uma acumulação de capital no pequeno comércio e nas artes mecânicas, permitindo a alguns mestres 
artesãos a manutenção de oficinas, e a um número maior a aquisição de escravos. Os grupos livres, dessa forma, davam continuidade à estrutura estamental ibérica, chegando mesmo a criar novas formas de hierarquização, como a elaborada entre pardos e pretos livres, mais visível quando os primeiros ocupavam cargos elevados na estrutura social. Assim sendo, os pardos que atuavam como oficiais mecânicos, como o pintor Manuel de Jesus Pinto, ajudante na obra das igrejas de São Pedro dos Clérigos no Recife e Santa Teresa em Olinda, ou os sapateiros Manuel Rodrigues de Azevedo, poeta popular de certo renome, e José Pereira, estavam mais próximos dos oficiais mecânicos pretos por sua condição social. Enquanto aqueles que ocupavam postos de capitães mores ou advogados se aproximavam das elites brancas, como Coronel Nogueira, do Regimento de milícia parda do Recife, que recebeu a Ordem de Cristo em 1809, embranquecendo-se extra-oficialmente e se distinguindo consideravelmente dos outros homens de $\operatorname{cor}^{37}$.

Entretanto, personagens como o Coronel Nogueira ascendiam a cobiçados postos, em geral reservados à elite branca, não se identificavam como pardos, uma vez que eram embranquecidos pelo imaginário dominante. Os pardos que se destacavam por conseguirem alcançar uma situação sócioeconômica estável nas vilas açucareiras eram personagens como José Rabelo de Vasconcelos, pintor e proprietário de ateliê, autor do forro do Convento Franciscano de Igarassu em 1759; Felipe Alexandre da Silva, entalhador, e João Vital Correia, pintor e dourador. Além dos já mencionados Manuel de Jesus Pinto, Manuel Rodrigues de Azevedo e José Pereira, famosos através da pena do cronista Domingos de Loreto Couto.

Mas, por trás desses personagens, existia um grupo bem maior de sapateiros, pintores e artífices pardos sem destaque nos registros de obras famosas ou nos escritos dos letrados, como Germano Soares que, em 1778, foi nomeado governador da corporação de ofício de pescadores do Recife, e daqueles pescadores pardos anônimos, seus correligionários ${ }^{38}$. Se no século XVI a pesca era uma atividade realizada principalmente por índios e reinóis, no século XVIII tal situação já estava 
bastante diferente: o número de pardos exercendo a atividade de forma organizada era tal que lhes permitiu eleger um dos seus como governador de sua corporação.

As corporações de ofício, no século XVIII, assimilavam grande número de pretos e pardos, livres e libertos, que se associavam aos escravos em busca de controle e regulamentação profissional ${ }^{39}$. Esta era a situação de Domingos Ferreira Ribeiro, preto forro governador da corporação de ofício dos pretos ganhadores do Recife em 1777, de Feliciano Gomes dos Santos, também preto, governador da mesma corporação em 1778, e de Josefa Lages, preta forra governadora das pretas ganhadeiras de Fora de Portas, do Recife, no período. Todos ambulantes, negros de ganho apesar de livres, que faziam parte de corporações de ofício que integravam também escravos ${ }^{40}$.

A população livre de pretos e pardos se ocupava quase sempre das mesmas atividades mecânicas que os escravos urbanos. E dentre as principais profissões exercidas pelos escravos no Recife do século XVIII estavam os canoeiros, pescadores, carpinteiros, marcadores de caixas de açúcar e os ganhadores, categoria que incluía carregadores, vendeiros, artesãos e barbeiros, além das ganhadeiras. E como as nomeações de governadores sugerem, muitas vezes as mesmas profissões eram exercidas por homens e mulheres livres de cor. Se não eram ambulantes, como ganhadeiras, camaroeiros e caranguejeros, esses trabalhadores instalavam suas tendas ou bancas de comércio nos mercados ou ao longo da ponte holandesa entre Recife e Santo Antônio. Uma participação efervescente no comércio interno dessa cidade que já era intensa no século XVII ${ }^{41}$.

Essa diversidade de atividades gerou a estrutura de corporações de ofício sancionada pelo governo da capitania, onde cada profissão se organizava e elegia um representante, um governador, que, por sua vez, estava subordinado a uma hierarquia militar cujo comandante era o Rei do Congo, um escravo eleito por seus pares, encarregado pela administração colonial de manter a ordem entre os escravos urbanos. 
A organização do Rei do Congo surgiu em Pernambuco em 1674, a partir da Irmandade de Nossa Senhora do Rosário dos Homens Pretos do Recife. Sua eleição era anual, realizada em suntuosa procissão onde predominavam os atabaques, trombetas e pandeiros, com os participantes vestidos com pompa e luxo barroco, em uma festividade onde se misturavam as tradições africanas e a imagem barroca necessária para sua aceitação pela sociedade colonial ${ }^{42}$.

Mas o Rei do Congo assumia também um papel de controle social, subordinando às corporações de ofício de escravos e recebendo da administração colonial não apenas a permissão para as celebrações anuais, mas também sua institucionalização através das patentes de governadores de ofício concedidas pela administração imperial: no século XVIII o governador de Pernambuco passava patentes aos governadores das corporações de ofício subordinando-os ao Rei do Congo ${ }^{43}$.

Essas corporações, em Recife e Olinda, eram imagens vívidas da complexidade das relações entre os pobres no meio urbano açucareiro, pois se por um lado congregavam escravos e livres de uma mesma profissão, por outro discriminavam membros por suas origens étnicas. Dentre as corporações que aceitavam escravos e livres estava a dos capineiros de Recife e Olinda, a dos pescadores de alto de Olinda, a das pretas boceteiras do Recife, a dos camaroeiros de Olinda, a dos pescadores, a dos ganhadores e a dos marcadores de caixa, estas últimas todas do Recife. Por outro lado, era possível encontrar corporações que restringiam seus membros a grupos étnicos determinados, como a do povo Arda da Costa da Mina, a da nação Sabarú, também da Costa da Mina, e a da denominada 'nação do Gome'44.

A situação dessas corporações era similar àquela das irmandades de pretos que apesar de congregarem escravos e libertos reproduziam a rivalidade existente entre nações africanas e seus descendentes crioulos. A Irmandade do Senhor Bom Jesus dos Martírios do Recife, por exemplo, em seu compromisso de 1776, descrevia as pessoas que podiam ser aceitas ao estabelecer que: 
todas as pessoas assim solteiras, como casados de cor preta que quiserem entrar nesta Irmandade farão seu Requerimento à Mesa pelos Irmãos Zeladores, e se procedera a informação do procedimento e naturalidade, que não sejam do gentio de Guiné ou do Reino de Angola: sendo se achem isentos destas duas naturalidades o Irmão Provedor mandara pelo Escrivão da Irmandade assentar o seu nome no Livro dos Irmãos, fazendo declaração da esmola que deu de sua Entrada. ${ }^{45}$

$\mathrm{Ou}$ seja, a irmandade aceitava tanto libertos quanto escravos, desde que não fossem gentios de Guiné ou Angola, ou seja, bantus ou iorubás, a grande maioria dos africanos de Pernambuco, o que terminava por limitar seus membros aos crioulos, os descendentes de africanos nascidos na América.

Mas as corporações de ofício não eram as únicas agremiações de artesãos nos núcleos urbanos canavieiros. No século XVIII, algumas irmandades leigas também se organizaram por ofícios em Recife, como a Irmandade de São Crispin e de São Crispiano, de sapateiros, a Irmandade de São José, de carpinteiros e marceneiros, e a Irmandade de Santo Elói, de ourives de prata. E apesar da existência de outras irmandades específicas para pretos livres e escravos, como a de Nossa Senhora do Rosário dos Pretos, a de São Benedito e a de Santa Ifigênia, além das irmandades de homens pardos, como a de Nossa Senhora do Livramento, a de Nossa Senhora de Guadalupe e a de Nossa Senhora do Amparo, as irmandades de ofício terminaram por congregar homens de cor livres, juntamente com artesãos brancos ${ }^{46}$.

Essas irmandades de caráter profissional, além de sua função religiosa e assistencialista, também se apresentavam como órgãos regulamentadores do exercício da profissão, como a Irmandade do Patriarca São José, no Recife, instituída em 1735, que congregava carpinteiros, pedreiros, marceneiros e tanoeiros. Uma de suas funções principais era a fiscalização do exercício dessas atividades, com seus juízes e provedores controlando as obras em andamento na vila e embargando qualquer obra levada a cabo sem a participação de um irmão da confraria. Além disso, 
seu compromisso determinava que todo marceneiro, carpinteiro, pedreiro e tanoeiro que não quisesse fazer parte da confraria fosse obrigado a pagar taxas anuais para continuar a trabalhar no Recife. Por outro lado, do ponto de vista da composição social, esta irmandade aceitava tanto livres quanto escravos de ganho que fossem artesãos de qualquer das quatro mencionadas artes, desde que a obrigação do pagamento das anuidades recaísse sobre seus senhores ${ }^{47}$.

Nesse contexto, em corporações ou irmandades, as condições de vida dos pardos e pretos livres aproximava-os. E o número de suas irmandades nos núcleos urbanos de Pernambuco foi crescente a partir do final do século XVII. Em vilas canavieiras como Serinhaém pululavam as irmandades de homens de cor: como a Irmandade de Nossa Senhora do Livramento dos Homens Pardos da Vila de Serinhaém ${ }^{48}$.

Também o Cabo de Santo Agostinho possuía uma irmandade parda sob a mesma invocação, além de irmandades de pretos, como a de Nossa Senhora do Rosário dos Homens Pretos. Cada confraria destas era gerada pelo crescimento do número de pretos e pardos, livres e escravos, nas povoações da região ${ }^{49}$.

No século XVIII, as irmandades de cor em Recife e Olinda incluíam a Irmandade do Rosário dos Pretos, existente em ambos os núcleos urbanos, a Confraria de Nossa Senhora de Guadalupe dos Homens Pardos, em Olinda, a Irmandade do Senhor Bom Jesus dos Martírios, de pretos cativos e libertos, no Recife, entre outras ${ }^{50}$. Além disso, os livres de cor também podiam participar de irmandades de caráter profissional. Um conjunto que ilustra o grande número de homens e mulheres de cor nos centros urbanos canavieiros, inclusive entre as camadas livres, a partir do século XVII, assim como sua interação com o imaginário dominante, haja vista a inserção das irmandades na estrutura católica colonial.

A relação entre o trabalho escravo e o trabalho livre nas vilas açucareiras, no entanto, a despeito da convivência em irmandades e corporações, era de competição, com o trabalho escravo predominando. Em meados do século XVIII, ocorreu uma 
disputa na Câmara do Recife entre os oficiais livres e os senhores de escravos artesãos devido ao fato de os juízes das corporações negarem-se a submeter artesãos escravos ao exame obrigatório para a licença de trabalho. Diante das queixas dos senhores, a Câmara vetou a proibição e os artesãos escravos voltaram a ser avaliados para novas licenças de trabalho ${ }^{51}$.

Ter a Câmara do Recife preferido apoiar o trabalho escravo não é surpreendente em uma sociedade escravista, mas o embargo feito pelos juízes de ofício ilustra, além do peso que a concorrência oferecida pela mão-de-obra escrava exercia sobre os artesãos livres, o desenvolvimento alcançado pelos grupos sociais atrelados ao trabalho mecânico livre no século XVIII, que os capacitou, mesmo momentaneamente, a negar a participação do trabalho escravo no mercado urbano.

$\mathrm{E}$ apesar da ferrenha pressão exercida pelo trabalho escravo, obreiros livres continuaram a existir e, muitas vezes, prosperar nos núcleos urbanos canavieiros. Um exemplo foi o mestre pedreiro Manoel Gomes de Oliveira que, em 1715, podia ser encontrado reclamando à Coroa pagamento por uma empreitada realizada no Forte do Brum, pela qual a Câmara de Olinda lhe ficara devedora. Sua prosperidade transparece no fato de ter sido capaz de realizar a reforma às suas custas. Caso semelhante foi o do mestre Nicolau Coelho de Albuquerque, proprietário de uma fundição no Recife, que em 1768 recebeu uma encomenda para a feitura de um sino destinado à Igreja da Estância. Ele não apenas executou a obra gratuitamente como arcou com as despesas de uma arrouba e duas libras de metal, utilizados na fundição da peça ${ }^{52}$.

Assim, de pretos forros, pardos embranquecidos, corporações de ofício e mercadores brancos, eram compostas as camadas livres urbanas das cidades açucareiras da América portuguesa. Grupos sociais que começaram a se constituir e diversificar no século XVII, com o crescimento demográfico e urbano, e que no XVIII passaram a ser alvo de tentativas de enquadramento na tipologia social da ordem estamental barroca. Era a plebe do açúcar que atuava na construção 
cotidiana de um mundo açucareiro bem distinto dos engenhos e canaviais.

\begin{abstract}
SILVA, Kalina Vanderlei. The Sugar Populace: Free People in the Recovery of the Portuguese Jurisdiction of the Captaincy of Pernambuco - Brazil $17^{\text {th }}$ to $18^{\text {th }}$ centuries. História, v.28, n.1, p.215-242, 2009.
\end{abstract}

\begin{abstract}
This paper is an analysis of the social structure of the Pernambucan sugar society stemming from the recovery of the Portuguese jurisdiction of the captaincy of Pernambuco in 1654, and focusing specifically on the free urban social groups that had developed significantly under Dutch administration. Taking into consideration chroniclers' accounts, inquisitorial data and official documents, we seek to analyze the social changes that had surged during the new Portuguese government of the late $17^{\text {th }}$ century in Pernambuco.
\end{abstract}

Keywords: Pernambuco; Sugar society; Portuguese government.

\title{
NOTAS
}

${ }^{1}$ Para o quadro político da área canavieira nos séculos XVII e XVIII: ACIOLI, V. L. C. Jurisdição e conflito - aspectos da administração colonial. 1 ${ }^{a}$ Ed. Recife: Ed. Universitária - UFPE/ Ed. UFAL, 1997, 230p; MELLO, E. C. A Fronda dos Mazombos - Nobres Contra Mascates Pernambuco 1666-1715. $1^{\text {a }}$ Ed. São Paulo: Companhia das Letras, 1995, 530p; MELLO, E. C.. Prefácio. In: COSTA, P. F. A. Anais Pernambucanos. Recife: Governo do Estado de Pernambuco, 1983, vol. 4, pp. XV-XXVI.

${ }^{2}$ Como pode ser visto em ACIOLI. Op. Cit. e MELLO. A Fronda dos Mazombos. Op. Cit, a segunda metade do século XVII foi palco para diversos conflitos de jurisdição entre a Câmara de Olinda, sede dos senhores de engenho de Pernambuco, o novo governo da Capitania e o Governo Geral. Esses conflitos se estenderam pelo século XVIII, culminando e ultrapassando a guerra dos mascates em 1710 e 1711.

${ }^{3}$ Cf. ACIOLI. Op. Cit. 
4 Para esses dados: SILVA, L. G. A Propriedade Mercantil e a Propriedade Colonial: Uma Abordagem Interpretativa da Economia Colonial do Nordeste (1690-1750). Caderno de História - Departamento de História-UFPE, Recife, 1987, vol. 02, p. 13, 15-16, 19; MELLO. In: COSTA. Op. Cit., p. XV-XXVI; e SILVA, L. G. A Faina, a Festa e o Rito Uma Etnografia Histórica Sobre as Gentes do Mar (Sécs. XVII ao XIX). $1^{a}$ Ed. São Paulo: Papirus, 2000, 245 p, p.85. BARICKMAN, B.J. Um Contraponto Baiano - Açúcar, Fumo, Mandioca e Escravidão no Recôncavo, 1780-1860. 1 $1^{\text {a }}$ Ed. Rio de Janeiro: Civilização Brasileira, 2003, 445p.

${ }^{5}$ SILVA. A Faina, A Festa e o Rito. Op. cit. p. 85

${ }^{6}$ GUERRA, F. Nordeste - Um Século de Silêncio (1654-1755). $1^{\text {a }}$ Ed. Recife: Companhia Editora de Pernambuco, 1984, 305p, p. 19.

${ }^{7}$ COSTA, P. F. A. Anais Pernambucanos. $2^{\mathrm{a}}$ Ed. Recife: Governo do Estado de Pernambuco, 1983, vol.2, 515p, p. 119; MELLO, E. C. de. Canoas do Recife: um Estudo de Microhistória Urbana. Revista do Instituto Arqueológico, Histórico e Geográfico Pernambucano. Recife, vol. 1, pp. 67-104,1978, p.67.

${ }^{8}$ A participação desses pobres na conquista do sertão pode ser vista em SILVA, K. V. Nas Solidões Vastas e Assustadoras - A Conquista do Sertão de Pernambuco pelas Vilas Açucareiras nos Séculos XVII e XVIII. $1^{\text {a }}$ Ed. Recife: CEPE, 2009, 280p. (No prelo)

9 PEREIRA, G. V. B. 'Breve Compêndio do que vai Obrando Neste Governo de Pernambuco o Senhor Antonio Luís Gonçalves da Câmara Coutinho' apud MELLO, J. A. G. de. Pernambuco ao Tempo do Governador Câmara Coutinho (1689-1690). Revista do Instituto Arqueológico, Histórico e Geográfico Pernambucano. Recife, vol. LI, pp. 257-300, 1979, p. 281-282; COPIA Authentica da Consulta do Conselho Ultramarino, de 28 de Novembro de 1691, acerca da construção de uma nova Casa da Camara, na cidade de Olinda, e de um caes junto do rio Beberibe. Apud O Caes do Varadouro em Olinda. Revista do Instituto Archeologico e Geográfico Pernambucano - RIAHGPE. Recife, Vol. XIII, $\mathrm{n}$ ○ 74, 1908, pp.586-590.

${ }^{10}$ MENEZES, J. L. M. Olinda e Recife - 1537-1630. Revista Oceanos - A Construção do Brasil Urbano - Comissão Nacional para a Comemoração dos Descobrimentos Portugueses, Lisboa, 2000, N. ${ }^{\circ} 41$. pp. 136-150.

${ }^{11}$ PEREIRA. Op. cit. p. 281.

12 Para Martiniére, esse crescimento deveu-se principalmente à migração portuguesa para a América, e ao aumento interno da população colonial. MARTINIÈRE, G. A Implantação das Estruturas de 
Portugal na América. In: MAURO, F (cord) . O Império Luso-Brasileiro 1620-1750. Nova História da Expansão Portuguesa. Vol. VII. $1^{\text {a }}$ Ed. Lisboa: Editorial Estampa, 1991, pp. 90-261, p. 212. Já Smith considera o crescimento demográfico fruto do aumento da migração portuguesa e do tráfico de escravos, ficando o crescimento vegetativo em segundo plano, a não ser em algumas capitanias como a Paraíba. SMITH, R. A Presença da Componente Populacional Indígena na Demografia História da Capitania de Pernambuco e suas Anexas na Segunda Metade do Século XVIII. In: ENCONTRO DA ASSOCIAÇÃO BRASILEIRA DE ESTUDOS POPULACIONAIS - ABEP, XIII, 2002. Ouro Preto: www.abep.org.br. p. 32

${ }^{13}$ Para a questão das levas migratórias, Cf. MARTINIÈRE. Op. cit. p. 213,214 . O grande fluxo do tráfico de escravos angolanos, iniciado em meados do XVI, tornou-se substancial a partir de $1600 \mathrm{com}$ o auge do açúcar em Pernambuco e Bahia. Além disso, entre 1660 e 1670, o tráfico no Atlântico Sul esteve sob o controle das elites pernambucanas. Cf. MILLER, J. C. A Economia Política do Tráfico Angolano de Escravos no século XVIII. In: PANTOJA, S; SARAIVA, F. J. Angola e Brasil nas Rotas do Atlântico Sul. $1^{\text {a }}$ Ed. Rio de Janeiro: Bertrand Brasil, 1999, pp. 11-67, p. 14-16.

${ }^{14}$ REIS, J. J. Rebelião Escrava no Brasil - A História do Levante dos Malês em 1835. Edição revisada e ampliada. São Paulo, Brasiliense, 2003, 665p, p. 14-15.

15 JANCSÓ, I. Na Bahia, Contra o Império - História do Ensaio de Sedição de 1798. $1^{\text {a }}$ Ed. São Paulo/Salvador: Hucitec/Edufba, 1996, 220p, p 57; PAULA, J. A. de. O Processo de Urbanização nas Américas no Século XVIII. In: ZMRECSÁNYI, Tamás (org.). História Econômica do Período Colonial. 2 ${ }^{a}$ Ed. São Paulo: Hucitec/ Edusp/ Imprensa Oficial, 2002, pp. 77-94, p. 89; MATTOSO, K. M. de Q. Bahia: A Cidade de Salvador e seu Mercado no Século XIX. $1^{a}$ Ed. Salvador: Hucitec, 1978, 300 p, p. 132. Devemos observar que um estudo comparativo entre os números populacionais para os diferentes núcleos urbanos da América portuguesa é uma tarefa complicada, visto que cada estimativa é dada seguindo parâmetros e fontes diferentes.

${ }^{16}$ JANCSÓ. Op. cit. p. 85; MATTOSO. Op. Cit. p.159-160.

${ }^{17}$ CARTA de Duarte Coelho a El Rei de 15 de 12 de 1540. Apud PORTO, C. Nos Tempos de Duarte Coelho. $1^{a}$ Ed. Recife: Imprensa Universitária/ Universidade Federal de Pernambuco, 1968, 120p. 
18 PIERONI, G. Os Excluídos do Reino: a inquisição portuguesa e o degredo para o Brasil colônia. $1^{\text {a }}$ Ed. Brasília: Ed. UNB/São Paulo: Imprensa Oficial, 2000, 305p, p. 268, p.270.

${ }^{19}$ Idem, p. 270, 284.

${ }^{20}$ PRIMEIRA Visitação do Santo Ofício às Partes do Brasil; Denunciações e Confissões de Pernambuco 1593-1595.1 $1^{a}$ Edição conjunta fac-símile. Recife: FUNDARPE, 1984, 667p.

${ }^{21}$ Veremos que nos séculos XVII e XVIII essa atividade era dominada por negros livres e escravos. Cf. SILVA, L. G. Os Pescadores na História do Brasil. Vol. 1 (Colônia e Império). $1^{\text {a }}$ Ed. Recife: Comissão Pastoral dos Pescadores/Vozes, 1988, 168p; SILVA. A Faina, a Festa e o Rito Uma Etnografia Histórica Sobre as Gentes do Mar (Sécs. XVII ao XIX). Op.cit.

${ }_{22}$ Todas as informações relativas aos inquéritos do Visitador em Pernambuco foram retiradas de PRIMEIRA Visitação do Santo Ofício às Partes do Brasil; Denunciações e Confissões de Pernambuco 1593-1595. Op. Cit, p. 79, 212, 325, 425. Já as referências aos artífices escravos no XVII estão em SILVA. A Propriedade Mercantil e a Propriedade Colonial: Uma Abordagem Interpretativa da Economia Colonial Do Nordeste (1690-1750). Op. cit. p.25-26.

${ }^{23}$ JANCSÓ. Op. cit. p.84

${ }^{24}$ ARAÚJO, U. C. de. A Bahia no Tempo dos Alfaiates. In: ARAÚJO, U. C. de (org.). II Centenário da Sedição de 1798 na Bahia. 1ª Ed. Salvador: Academia de Letras da Bahia, 1998, pp. 7-19,p. 11.

${ }^{25}$ MATTOSO. Op. cit. p. 284. JANCSÓ. Op. cit. p. 83.

${ }^{26}$ MATTOSO. Op. cit. p. 285

${ }^{27}$ Essa é a opinião de SILVA. A Faina, A Festa e o Rito - Uma Etnografia Histórica Sobre As Gentes do Mar (Sécs. XVII ao XIX). Op. cit. p. 83

${ }^{28}$ SILVA. Os Pescadores na História do Brasil. Vol. 1 (Colônia e Império). Op. cit. p. 49,34, 49; SILVA. A Faina, A Festa e o Rito - Uma Etnografia Histórica Sobre As Gentes do Mar (Sécs. XVII ao XIX). Op. cit. p. 100-1.

${ }^{29}$ Para a inserção dos pobres livres açucareiros nas tropas da Coroa e sua participação na conquista dos sertões, CF. SILVA. Nas Solidões Vastas e Assustadoras. Op. Cit.

${ }^{30}$ Para observar a relação entre ordem estamental e realidade mestiça colonial, cf. SCHWARTZ, S. B. Segredos Internos - Engenhos e Escravos na Sociedade Colonial, 1550-1835. $3^{a}$ Reimpressão. São Paulo: Companhia das Letras, 2005, 475p; e PONTES, K. V. Mulatos: Políticos e 
Rebeldes Baianos. Salvador, 2000, Dissertação (Mestrado em História) FFCH,UFBA.

${ }^{31} \mathrm{O}$ conceito de plebe aqui empregado foi elaborado a partir da obra de Moraes Silva, do final do XVIII, que apresenta tanto a noção de plebe que vemos também em Loreto Couto -, como a de povo. SILVA, A. M. Dicionario da Lingua Portugueza Composto por Antonio de Moraes Silva. [1. ${ }^{a}$ edição de 1789]. Lisboa: Impressão Regia, 1831, 02 tomos, tomo II, p. 476, 499.

${ }^{32}$ COUTO, D. L. Desagravos do Brasil e Glória de Pernambuco. $1^{\text {a }}$ Ed. Recife: Fundação de Cultura Cidade do Recife, 1981, 561p, p. 226-227.

${ }^{33}$ TOLLENARE, L. F. de. Notas Dominicais. $1^{\text {a }}$ Ed. Recife: Governo do Estado de Pernambuco, 1978, 272p, p. 43-44, 75-76

34 VENÂNCIO, R. P.; FURTADO, J. F. Comerciantes, Tratantes e Mascates. In: DEL PRIORE, M. Revisão do paraíso - os brasileiros e o estado em 500 anos de história. $1^{\text {a }}$ Ed. Rio de Janeiro: Campus, 2000, pp. 93-113, p. 101-103.

${ }_{35}$ SOARES, C. M. As Ganhadeiras: Mulher e Resistência Negra em Salvador no Século XIX. Afro-Ásia-Ceao/UFBA, Salvador, N. ${ }^{\circ} 17,1996$; SILVA, M. B. N. Colonização Portuguesa no Brasil: A População Feminina e Sua Sobrevivência Económica no Fim do Período Colonial. Revista de Ciências Históricas - Universidade Portucalense, Porto, vol. VI, pp. 257-269, 1991, p. 259; CARVALHO, M. J. M. de. Liberdade Rotinas e Rupturas do Escravismo - Recife 1822-1850. 1a Ed. Recife: Ed. Universitária-UFPE, 1998, 353p.

${ }^{36}$ TINHORÃO, J. R. As Festas no Brasil Colonial. 1a Ed. São Paulo: Editora 34, 2000, 174p, p. 79; MARCÍLIO, M. L. A População do Brasil Colonial. IN: BETHEL, L (org). América Latina Colonial, vol. 2. História da América Latina. $1^{\mathrm{a}}$ Ed. São Paulo: EDUSP, 1999, 865p, p. 327.

${ }^{37}$ Esses personagens foram mencionados em: COUTO. Op. Cit, p. 330331; COSTA. Anais Pernambucanos. Op. cit. vol. 6, p.46; e KOSTER, H. Viagens ao Nordeste do Brasil. $2^{\mathrm{a}}$ Ed. Recife: Governo do Estado de Pernambuco, 1978, 480p, p. 376.

38 Esses podem ser encontrados na Coleção Patentes Provinciais (PP), livro 3 fl. 92. APEJE - Arquivo Público Jordão Emerenciano, Recife-PE.

${ }^{39}$ COSTA. Anais Pernambucanos. Op. cit. vol. 6, p. 144-5

${ }^{40}$ TORRES, C. V. Um Reinado de Negros em um Estado de Brancos Organização de Escravos Urbanos em Recife No Final do Século XVIII e Início do XIX (1774-1815). Recife, 1997, Dissertação (Mestrado em História) - FFCH, UFPE; PP, livro 3, fl.49, 26/10/1777. APEJE; PP, livro 3, fl.158, 14/11/1778. APEJE. 
${ }^{41}$ TORRES. Op. cit. p. 49, 54-55,65.

${ }^{42}$ MELLO, J. A. G. de. Alguns Aditamentos e Correções. In: COSTA. Anais Pernambucanos, op. Cit. Vol. X, pp. CDXC-DXVI, p. DIX; TINHORÃO. Op. Cit.; TORRES. Op. cit.

${ }^{43}$ Para José Antônio Gonçalves de Mello, a organização do rei do Congo coexistia com a do Rei de Angola e rei dos crioulos em Pernambuco. MELLO. Alguns Aditamentos e Correções. In: COSTA. Anais Pernambucanos. Op. cit. vol. 10, pp. CDXC-DXVI, p. DIX-DX. No entanto, segundo José Ramos Tinhorão, a referência ao 'Rei de Angola' seria apenas outra terminologia para a mesma instituição. TINHORÃO. Op. cit. p. 88.

${ }^{44}$ MANUSCRITOS da Igreja de Nossa Senhora do Rosário dos Homens Pretos. Apud MELLO. Alguns Aditamentos e Correções. Op. Cit. p. DX, DXI; e PP, livro 2, fl. 198, APEJE; PP, livro 2, folha 129/129v, APEJE; PP, livro 2, folha 114v. APEJE

${ }^{45}$ COMPROMISSO da Irmandade do Senhor Bom Jesus dos Martyrios, cap. VI. AHU - Arquivo Histórico Ultramarino (Projeto Resgate), cód. 1302. Fl. 06. Grifo original.

${ }^{46}$ ARAÚJO, R. C. Festas: Máscaras do Tempo - Entrudo, Mascarada e Frevo no Carnaval do Recife. $1^{\mathrm{a}}$ Ed. Recife: Fundação de Cultura Cidade do Recife, 1996, 423p, p. 69; REIS, J. J. A Morte é uma Festa. - Ritos Fúnebres e Revolta Popular no Brasil do século XIX. $1^{\text {a }}$ Ed. São Paulo: Companhia das Letras, 1991, 357p, p. 52

${ }^{47}$ COMPROMISSO da Irmandade do Patriarca São José dos quatro Ofícios anexos, carpinteiros, pedreiros, marceneiros e tanoeiros da Vila de Santo Antônio do Recife. AHU, códice 1301. Apud CAVALCANTI, V. Religiosidade e morte: instrumentos do projeto colonial português. Historical Archeology in Latin America - Columbia, the University of South Carolina, 1995, pp. 30-31, p. 39.

${ }^{48}$ COMPROMISSO da Irmandade de Nossa Senhora do Livramento dos Homens Pardos da Vila de Serinhaém. AHU, códice 1664, folha 4.

${ }^{49}$ AHU, códice 1683; QUINTÃO, A. A. As Irmandades de Pretos e Pardos em Pernambuco e no Rio de Janeiro na época de D. José I: Um Estudo Comparativo. In: SILVA, M. B. N. da (org.). Brasil - colonização e escravidão. $1^{a}$ Ed. Rio de Janeiro: Nova Fronteira, 2000, pp. 163-176, p. 164.

${ }^{50}$ ASSIS, V. A. de. Pretos e Brancos - A Serviço de Uma Ideologia de Dominação (Caso das Irmandades do Recife). Recife, 1988, Dissertação (Mestrado em História) - FFCH, UFPE.; QUINTÃO. Op. cit. p. 17; AHU, códice 1302. 
${ }^{51}$ COSTA. Anais Pernambucanos. Op. Cit. vol. 6, p. 144-145.

${ }^{52}$ Esses casos podem ser vistos em LIVRO $10^{\text {a }}$ de Ordens Reais: Provisões e Cartas Régias (1717-1720). Fl 23. IAHGPE - Instituto Arqueológico, Histórico e Geográfico de Pernambuco; COSTA, F. A. P. Estudo Histórico-Retrospectivo Sobre as Artes em Pernambuco. Revista do Instituto Arqueológico, Histórico e Geográfico de Pernambuco, Recife, ano XXXVIII, vol. IX, n 54, pp. 3-45, p. 35.

Artigo recebido em 03/2009. Aprovado em 05/2009 